\title{
A survey on commercial fish feed used at Fulpur area in Mymensingh district
}

\author{
M. K. Alam, M. A. B. Habib and M. S. Tahmid \\ Department of Aquaculture, Bangladesh Agricultural University, Mymensingh-2202, Bangladesh. E-mail: \\ khurshedalam@nourish-poultry.com
}

\begin{abstract}
This study was performed in Fulpur upazila under Mymensingh district for the period of 13 months from August 2010 to August 2011 to know the socio-economic and aquaculture status of fish farm owners and to assess the nutritive value of commercial fish feed available at Fulpur upazila of Mymensingh district. Fish farm owners were prominent in the study area and majority was illiterate but had the ability of signature. The monoculture and polyculture farm in the studied area were established in ranged from 1995 to 2005, respectively. Most of the fish farm owners followed polyculture system and had small farm area. Majority of fish farm owners leased water body for aquaculture. The minimum size of the farm was 0.162 ha and maximum size of the farm was 3.722 ha. The average depth of the water body in winter season was 1.61 meter and in summer season was 2.32 meter. Majority of fish farm owners followed proper pre-stocking and post stocking management with maintaining high stocking density of fish and using either commercial or farm made fish feed. Among the commercial fish feed tested the highest value of moisture was found in Aftab feed, protein in Nourish feed, lipid in CP feed, ash in Aftab feed, fibre in ACl feed and carbohydrate in ACl feed. Most of the commercial fish feed maintain standard level of chemical composition.
\end{abstract}

Keywords: Nutritive value, Economic status

\section{Introduction}

Bangladesh is very rich in inland capture fish production. But now-a-days capture fish production is decreasing day by day due to different causes. Such as agricultural pollution, industrial pollution, natural calamity etc. Fish of the beels along with other aquatic organisms are silent victims of chlorine sub-lethal toxicity resulting from different types of pollutants (Bernet et al., 1999). Fish production is also decreasing due to natural causes like flood, drought etc (Chakraborty, 2009). At present, total poultry and fish feed companies are 54 such as Saudi-Bangla Feed mill, Fresh Feed mill, Quality Feed mill, Nourish Feed mill etc and there are about 25 commercial fish feed industries in Bangladesh (Rob, 2008). The well-known industries are Al-Momen Feed mill, Aktel Feed Mill, Rahat Feed Mill etc in the Mymensingh region. Fish feed and feeding play important role in the sustainable development of aquaculture. Better feed composition will result in higher fish production and lower feed cost. In feed development, there should have a provision of continuous investigation of raw materials and feed management in the mills and industry.

\section{Materials and Methods}

Study area: This experiment was performed in Fulpur upazila under Mymensingh district.

Duration of the study: The present study was undertaken for the period of 13 months from August 2010 to August 2011.

Preparation of questionnaire: The questionnaire was prepared in accordance with the objectives of study. The questionnaire has two parts, one includes personal information and the other includes farm information.

Analytical methods: The proximate composition of different commercial fish feeds were analyzed in duplicate according to standard procedure given in Association of Official Analytical Chemists (AOAC. 2000). 
Moisture: The percentage of moisture was calculated using the following equation:

Moisture $(\%)=\frac{\text { Original sample weight }(\mathrm{g})-\text { Dried sample weight }(\mathrm{g})}{\text { Original sample weight }(\mathrm{g})} \times 100$

Ash: The percentage of ash was then determined.

Ash content $(\%)=\frac{\text { Weight of crucible with ash }(\mathrm{g})-\text { Weight of empty crucible }(\mathrm{g})}{\text { Weight of sample }(\mathrm{g})} \times 100$

\section{Crude Protein}

Crude protein of the samples was estimated by using Kjeltec 2020 digestor. A sample of $0.5 \mathrm{~g}$ and a blank was estimated in the digestion tube. For digestion at high temperature, $10 \mathrm{ml}$ of concentrated sulfuric acid and $1.1 \mathrm{~g}$ digestion mixture were added in the tube. Then the digestion tubes were set in digestion chamber fixing at $420^{\circ} \mathrm{C}$ for 45 minutes ensuring water supply, easier gas outlets etc. After digestion the tubes were allowed to cool and $5 \mathrm{ml}$ of sodium thio-sulphate $\left(\mathrm{Na}_{2} \mathrm{~S}_{2} \mathrm{O}_{3}, 33 \%\right)$ and $30 \mathrm{ml}$ sodium hydroxide $(\mathrm{NaOH})$ solution was added in each tube. Then the distilled extraction was collected with $25 \mathrm{ml}$ of Boric acid (4\%) and titrated with standard hydrochloric acid $(0.2 \mathrm{~N})$. The nitrogen values obtained was converted into percentage of crude protein by multiplying with a factor of 6.25 assuming that protein contains $16 \%$ nitrogen.

$\%$ Nitrogen $=\frac{\text { Milliequivalent of nitrogen }(0.014) \times \text { titrant value }(\mathrm{ml}) \times \text { strength of } \mathrm{HCL}}{\text { Sample weight }(\mathrm{g})} \times 100$

$\%$ Crude protein $=\%$ Nitrogen $\times 6.25$

\section{Crude Lipid}

Crude lipid was determined by extracting a weighed quantity (2-3 g) of samples with analytical grade acetone in ground joint Soxhlet apparatus. Extraction was allowed to continue by heating in the electric heater at the temperature of $70^{\circ} \mathrm{C}$ until clear acetone (without oil) was seen in siphon, which took about 3 hours. Then the round bottom flask of the apparatus was separated and the extract was transferred to a pre-weighed beaker and left for evaporation of acetone. After the evaporation of acetone, only the lipid was left in the beaker which was later calculated in percentage.

$\%$ Crude lipid $=\frac{\text { Weight of beaker with lipid }- \text { Weight of empty beaker }}{\text { Weight of sample }(\mathrm{g})} \times 100$

\section{Crude Fibre}

A small amount of finely ground sample (1-2 g) was taken into a filter crucible and was inserted into the hot extraction unit (Hot Extractor, Model-1017). Sufficient amount of pre-heated $0.128 \mathrm{M} \mathrm{H}_{2} \mathrm{SO}_{4}$ was added into the reagent heating system and few drops of octanol were added through the valves. The mixture was digested for 30 minutes. Acid was then removed from it by filtering and washing with boiling water. The residue in the flask was boiled with required amount of $0.223 \mathrm{M} \mathrm{KOH}$ for 30 minutes and then filtered with subsequent washing in boiling water and acetone. The residual content was then dried in an oven at $105^{\circ} \mathrm{C}$ for a few hours and then ignited in muffle furnace at $550^{\circ} \mathrm{C}$ for 3 hours. The loss of weight represented the crude fibre. Then percent crude fibre was calculated by the following formula:

Crude fibre $(\%)=\frac{\text { Oven dried weight of sample }(g)-\text { Ash weight of sample }(g)}{\text { Weight of sample }(g)} \times 100$ 


\section{Nitrogen Free Extracts (NFE)}

Nitrogen free extract (NFE), a soluble carbohydrate was calculated by subtracting the sum of the percentage contents of moisture, crude protein, lipid, ash and crude fibre from 100. Nitrogen free extract (NFE) was calculated as:

NFE $\%=\{100$ - (moisture + crude protein + crude lipid + ash + crude fibre $)\}$

\section{Processing and Analysis of Data}

The collected data were summarized, tabulated and analyzed according to the objectives of the study. A tabular method of analysis was followed in analyzing the collected information. For data analysis MS Word, Excel and SPSS were used.

\section{Results and Discussion}

\section{Marketing Type of Feed}

The marketing of feed was done in different ways. Some feeds were supplied in farm directly or via Dealer. The marketing chain of the company is given below by flow chart (Figure 1):

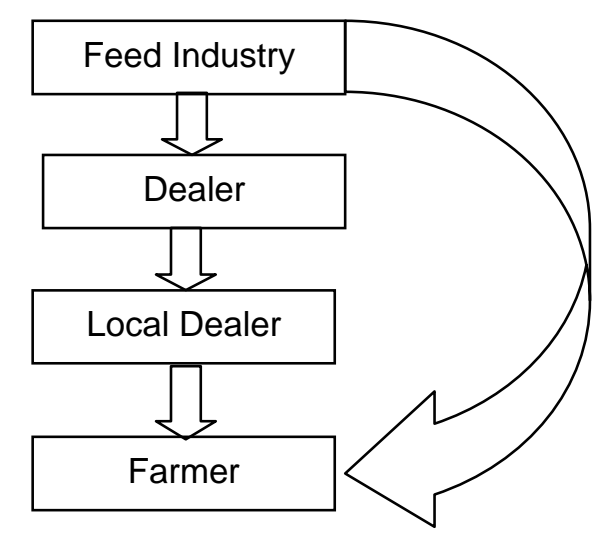

Fig. 1. Company feed marketing chain

Through the study, it was possible to gather information on availability and nutritive value of fish feeds at Fulpur of Mymensingh district. During the study period, proximate composition such as moisture, protein, lipid, ash, crude fibre and carbohydrate of different feeds were analyzed in the laboratory. Reports on the analysis of fish feeds are stated below:

\section{Moisture}

The mean moisture value of $\mathrm{ACl}$ fish feed, Nourish fish feed, Mega fish feed, Aftab fish feed, CP fish feed, Saudi Bangla fish feed and Quality fish feed are $11.77 \%, 10.38 \%, 10.06 \%, 17.72 \%, 11.76 \%$, $10.95 \%$ and $12.93 \%$, respectively. The maximum moisture was found in Aftab fish feed $(17.72 \%)$ and the minimum was in Mega fish feed (10.06\%).

\section{Crude Protein}

The mean crude protein value of $\mathrm{ACl}$ fish feed, Nourish fish feed, Mega fish feed, Aftab fish feed, CP fish feed, Saudi Bangla fish feed and Quality fish feed are 23.15\%, 31.67\%, 24.24\%, 25.85\%, 23.74\%, $26.65 \%$ and $23.92 \%$, respectively. The maximum crude protein content was found in Nourish fish feed (31.67\%) and the minimum crude protein was in ACl fish feed (23.15\%). 


\section{Crude Lipid}

The mean crude lipid values of ACI fish feed, Nourish fish feed, Mega fish feed, Aftab fish feed, CP fish feed, Saudi Bangla fish feed and Quality fish feed are 6.93\%, 8.60\%, 8.12\%, 6.40\%, 11.13\%, 9.66\%, and $9.60 \%$, respectively. The maximum crude lipid was found in CP fish feed (11.13\%) and the minimum crude lipid was in ACl fish feed (6.93\%).

\section{Ash}

The mean ash values of $\mathrm{ACl}$ fish feed, Nourish fish feed, Mega fish feed, Aftab fish feed, CP fish feed, Saudi Bangla fish feed and Quality fish feed are 8.51\%, 15.65\%, 23.15\%, 24.40\%, 21.11\%, 19.15\%, and $23.01 \%$, respectively. The maximum ash was found in Aftab fish feed (24.40\%) and the minimum was in $\mathrm{ACl}$ fish feed (8.51\%).

\section{Crude Fibre}

The mean crude fibre values of $\mathrm{ACl}$ fish feed, Nourish fish feed, Mega fish feed, Aftab fish feed, CP fish feed, Saudi Bangla fish feed and Quality fish feed are 7.9\%, 5.53\%, 5.71\%, 5.48\%, 5.84\%, 5.48\% and $4.33 \%$, respectively. The maximum crude fibre content was found in $\mathrm{ACl}$ fish feed $(7.9 \%)$ and the minimum was in Quality fish feed (4.33\%).

\section{Carbohydrate}

The mean carbohydrate values of ACl fish feed, Nourish fish feed, Mega fish feed, Aftab fish feed, CP fish feed, Saudi Bangla fish feed and Quality fish feed are $38.29 \%, 28.59 \%, 28.74 \%, 27.49 \%, 26.42 \%$, $28.10 \%$ and $29.53 \%$, respectively. The maximum carbohydrate was found in $\mathrm{ACl}$ fish feed (38.29\%) and the minimum was in CP fish feed (26.24\%).

During the study period it was found that about $90 \%$ farm used supplementary feed made by different companies and only $10 \%$ farm owners used homemade feed. Different types of factory feeds are used in Fulpur upazila. Most of these feeds are local ingredients of wich were not known to farmers. Hasan and Ahmed (2001) reported that mediated feeds were often used indiscriminately during disease outbreaks in hatcheries, nurseries and farms. Among the commercial fish feed tested the highest value of moisture was found in Aftab feed, protein in Nourish feed, lipid in CP feed, ash in Aftab feed, fibre in ACl feed and carbohydrate in $\mathrm{ACl}$ feed. Most of the commercial fish feed maintain standard level of chemical composition. As the manufacture of aqua feeds is new to Bangladesh, no specific regulations are existent to control their processing or sale. Therefore, it is necessary to take additional steps to enforce regulatory laws for the products and marketing of fish feed for the safeguard of the fish farmers and fish production. Each manufactured productions must be tested and certified by the government authority before marketing under the regulations to be practiced.

\section{References}

AOAC. 2000. Official methods of Analysis. 17th end. Association of Official Analysis Chemists, Washington DC. 2200 pp.

Bernet, D.H., Schmidt, W., Meier, P., Burkhardt - Holm and wahli, T. 1999. Histopathology in fish, Proposal for a protocol to asses aquatic pollution , J. of Fish Dis. 22(1): 25-34.

Chakraborty, B.K. 2009. Aquatic biodiversity of Someswari and Nethai River and Gharia and Nidaya Beel of Northern Bangladesh. In: Takumi K. Nakamura (Ed.). Aquaculture Research Progress, Nova Science, Publishers, New York, USA. : 3231-268.

Hasan, M.Z. and Ahmed. 2001. Issues in carp hatcheries and nurseries in Bangladesh, with special reference to health management .In primary Aquatic Animal health Care in Rural Small-scale Aquacultural Developemnt, Arthar, J.R., M. J. Phillips, r.O. Subansinghe, M.B. Reantaso and I. H. MacRae (eds.), FAO Fish Tech. Paper, 406:147-164.

Mollah, M.F.A. and Hossain, M.A. 1990. Effects of artificial diets containing different protein levels on growth and feed efficiency of catfish (Clarias batrachus). Indian J. Fish. 37(3): 251-259.

Rob, M.G.M. 2008. Bangladesh Poultry Directory. 8th Edition. Dhaka Book House, Dhaka. 35 pp.

Wilson, R.P. 2000. Channel catfish, Ictalurus puntatus. In: R.P. Wilson. (eds.) Handbook of Nutrient Requirement of Fisnfish. CRC Press, Boca Raton Ann Arbor, Boston, London. pp. 35-53. 